\title{
THE POTENCY OF SOURSOP LEAF WATER EXTRACT ON ACTIVATING GLP-1R, INHIBITING DPP4 AND FOXO1 PROTEIN BASED ON IN SILICO ANALYSIS
}

\author{
DINI SRI DAMAYANTI ${ }^{1,2}$, NURDIANA ${ }^{3}$, H. M. S. CHANDRA KUSUMA ${ }^{4}$, DJOKO WAHONO SOEATMADJI ${ }^{5}$
}

${ }^{1}$ Doctoral Program Medical Science, Faculty of Medicine, Universitas Brawijaya, Malang, 65145, Indonesia, ${ }^{2}$ Department of Physiology, Faculty of Medicine, Universitas Islam, Malang, 65144, Indonesia, 3Department of Pharmacology, Faculty of Medicine, Universitas Brawijaya, Malang, 65145, Indonesia, ${ }^{4}$ Department of Pediatric Medicine, Faculty of Medicine, Universitas Brawijaya, Malang, 65145, Indonesia, ${ }^{5}$ Department of Internal Medicine, Faculty of Medicine, Universitas Brawijaya, Malang, 65145, Indonesia. Email: dinisridamayanti@gmail.com

Received: 12 Dec 2018, Revised and Accepted: 10 Mar 2019

\section{ABSTRACT}

Objective: Soursop leaf contains alkaloids, terpenoids, flavonoids, acetogenin, and phenolics. Soursop leaf decoction is usually consumed as an antiobesity agent, even though its active compounds and its action mechanism are still unclear. Computational approaches have been developed to predict the ability of an active compound to bring about biological effects. This study was designed to predict the potency of soursop (Annona muricata Linn.) water extract for the activating of Glucagon-Like Peptide-1 Receptor (GLP-1R), Inhibiting Dipeptidyl Peptidase 4 (DPP4), and Forkhead Box Protein 01 (Fox01) protein using in silico analysis.

Methods: Identification of active compounds contained in soursop leaf water extract was carried out using physicochemical methods and Gas chromatography-mass spectrometry (GC-MS). They were then analyzed using computational analysis, i.e., potential analysis using the Way2drug web server. Protein interaction predictions of GLP-1R with the active compounds found in soursop leaf water extract using STITCH. The affinities of the active compounds of soursop leaf to the proteins DPP4 and Fox01 were also analyzed using molecular docking.

Results: Active compounds of the soursop leaf water extract contain 5-isopropenyl-3,8-dimethyl-1,2,3,3A, 4,5,6,7-octa hydro azulene (22.17\%) and 1,2-benzene dicarboxylic acid, diethyl ester (phthalic acid) (57.30\%). The active ingredients have not been shown to interact with GLP-1R. 5isopropenyl-3,8-dimethyl-1,2,3,3A, 4,5,6,7-octa hydro azulene and phthalic acid both have a weak affinity for DPP4, and only phthalic acid has a weak affinity with the Fox 01 protein.

Conclusion: Phthalic acid has a weak potential as an inhibitor of the DDP4 and Fox01 proteins.

Keywords: GLP-1 Receptor, DPP4, Fox01, soursop leaf (Annona muricata l.)

(C) 2019 The Authors. Published by Innovare Academic Sciences Pvt Ltd. This is an open access article under the CC BY license (http://creativecommons. org/licenses/by/4. 0/) DOI: http://dx.doi.org/10.22159/ijap.2019.v11s6.33549

\section{INTRODUCTION}

Traditional health services in Indonesia, especially in rural communities compared to urban communities. A total of $49 \%$ of the 89,753 households in Indonesia use traditional health services such as aromatherapy, and spas as medicinal treatment [1]. There is a belief that herbal treatments can cure various diseases and are cheap [2,3]. Many Indonesian people believe that traditional medicine is better than modern medicine [1], and continue to consume the traditional medicine, often in the form of herbal decoctions [3].

One of the herbs that is widely used in traditional health treatments is soursop leaves (Annona muricata Linn.). Soursop plants are native to South America and have now spread to Southeast Asia, Southern Europe, South China, Africa, Australia, and the Pacific. Soursop is a type of plants with dense leaves and a height ranging from 8-9 meters. The leaves are oval-shaped, and its size are $6.5 \mathrm{~cm} \mathrm{x} 2.5 \mathrm{~cm}$ they are dark green and shiny on the top. Its flowers are single flowers which appear on stems, branches, and twigs. Its fruit can be consumed. The young fruit is dark green with a rough surface, and there are bumps like spines. When it is ripe, it becomes brownish-yellow, and the fruits texture is fibrous, soft, and segmented. The fruit tastes sweet-sour with a pineapple-like aroma. The seeds are blackish-brown and ovalshaped, with a size of $2.5 \times 0.5 \mathrm{~cm}$ (fig. 1) [4].

As an herbal plant, soursop leaves are consumed by the community as an antihypertensive agent [5], anti-diabetic [6], anti-inflammatory [7], anti-obesity [8], antioxidant [9], anti-hyperlipidemic [10], antirheumatic [11], antibacterial [12], antidepressant [13], and anticancer [14]. Soursop leaves contain active compounds, including acetogenin [15], alkaloids, terpenoids, flavonoids, coumarins, steroids, fatty acids, phlorotannins, phenolics, tannins, and saponins [16]. Although soursop leaves have been shown to have anti-obesity effects in multiple in vivo studies, the mechanism by which its active ingredients, individually or in combination, might act as anti-obesity agents have not been studied.

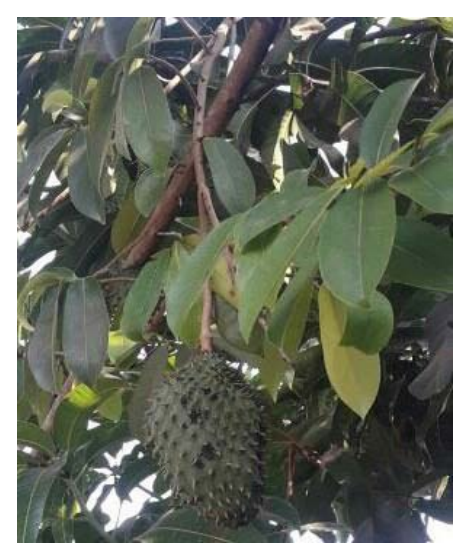

Fig. 1: Soursop leaves and fruit (private collection)

Obesity is a condition caused by an imbalance between food intake and energy expenditure that causes the accumulation of adipose cells in the subcutaneous and visceral tissue. Data from the World Health Organization (WHO) stated that the number of obese patients in the world had increased dramatically since 1980. This increase in the number of obese patients is related to environmental factors such as unhealthy eating habits and a lack of activity [17]. Obesity is a predisposing factor for type 2 diabetes mellitus, fatty liver, cardiovascular disease, reproductive disease, malignancy, osteoarthritis and psychosocial disorders [18]. 
The development of pharmacological treatments for obese patients emphasizes the role of intestinal peptides, namely GLP-1 [19]. Several studies have shown impaired function of GLP-1 in obese patients. This is presumed to be the cause of a decrease in hunger suppression signaling and an increase in gastric emptying [20]. GLP1 is a peptide hormone composed of 30 peptides. GLP-1 is secreted by intestinal $\mathrm{L}$ cells in response to food in the food channel, especially for glucose, protein, a lipid; this is parasympathetic nerve activity. L cells are widely distributed in the jejunum distal, ileum, colon and rectum [21]. The proglucagon gene encodes GLP-1. Preproglucagon genes are expressed in the L cells, pancreatic $\alpha$ cells and neurons in the solitary tract.

Post-translation of preproglucagon genes increases the expression of the proglucagon gene. The type of peptide formed by proglucagon depends on the activity of the specific Prohormone Convertase (PC) enzyme in the tissue. Prohormone Convertase-2 (PC2) expression is abundant in pancreatic $\alpha$ cells. This condition causes proglucagon to synthesize Glucagon peptides, Intervening Peptide-1 (IP1), and Major Proglucagon Fragment (MPGF). As for L cells in the intestine, the activity of the Prohormone Convertase-1 (PC1) enzyme will break down proglucagon to GLP-1, GLP-2, oxyntomodulin, glicentin, and Intervening Peptide-2 (IP2) [22].

GLP-1 is secreted in 2 active forms, namely GLP-1 (7-36 amino acid residues) and GLP-1 (7-36) amide. GLP-1 (7-36) amide is the most distributed form in the circulatory system. Structurally, GLP-1 is similar to glucagon. GLP-1 is composed of N terminal segments (1-7 amino acid residues), 2 helix segments (7-14 and 18-29), and connecting segments (15-17 amino acid residues. GLP-1 is eliminated from the circulatory system via excretion via the kidneys, and liver, and inactivation by the enzyme DPP4. The half-life of GLP1 is about 1-2 min due to inactivation by the DPP4 enzyme in the circulation. DPP4 will cut GLP-1 (7-36) and GLP-1 (7-36) amides to form GLP-1 (9-36) which is inactive [21].

GLP-1 receptors are located in the islet of Langerhans (cells $\alpha, \beta, \delta$ pancreas), gastric parietal cells, brain, heart, lung, and kidneys. This receptor is not found in skeletal muscle tissue, liver, or adipose tissue [18]. GLP-1 receptors belong to the G protein couple receptor (GPCR) family. This receptor has an extracellular N-terminal domain (NTD) consisting of 100-150 peptides that are associated with integral membrane core domains (J domains) [23].

GLP-1 plays a role in regulating blood glucose levels through the regulation of the function of the islets of Langerhans, which stimulates insulin secretion and inhibits glucagon. Unlike sulfonylurea, GLP-1 controls blood glucose levels with dependent glucose properties, thus preventing the occurrence of side effects such as hypoglycemia. GLP-1 also decreases gastrointestinal motility, inhibits gastric emptying, decreases food intake and causes weight loss [24]. The central mechanism of GLP-1 reduced body weight was inhibit the action of neurons that produce the orexigenic neuropeptide Y (NPY) and Agouti-related protein (AgRP) and increase the activity of proopiomelanocortin neurons (POMC) which produce $\alpha$-Melanocytestimulating hormone ( $\alpha$-MSH) in the hypothalamus, causing decreased appetite and food intake and increased energy expenditure [25].

The insulinotropic mechanism of GLP-1 is related to its ability to increase Cyclic Adenosine Monophosphate (cAMP) levels and inducing glucose metabolism in pancreatic $\beta$-cells. The bond between GLP-1 and its receptor (GPCR) activates the enzyme adenylate cyclase. Increased levels of cAMP will cause (1) an increase in glucose metabolism to produce ATP, (2) closure of potassium canals and cell membrane depolarization, and (3) opening of calcium channels in the cell membranes and intracellular calcium depots to increase the intracellular calcium levels. Furthermore, increased levels of intracellular calcium will cause insulin exocytosis; in addition to increasing insulin secretion, GLP-1 also activates glucokinase and Glucose Transporter 2 (GLUT2) genes $[19,26]$.

GLP-1 increases the differentiation of progenitor cells in the pancreatic ducts into new pancreatic $\beta$-cells and inhibits $\beta$-cell apoptosis through the inhibition of pro-apoptotic cytokines and caspase enzyme activity [19]. GLP-1 also has a proliferative effect on pancreatic $\beta$-cell, which on pancreatic $\beta$ cells occur via the Epidermal
Growth Factor Receptor (EFGR) activation mechanism. GLP-1 will cause EGFR post-translation. The next signaling activates the Phosphoinositide 3-Kinases (PI3K) and causes the translocation of Fox01 from the nucleus to the cytoplasm. The phosphorylation of Fox01 causes the proliferation of pancreatic $\beta$-cells $[27,28]$.

Fox01 is a transcription factor protein which belongs to a family of forkhead proteins with the characteristic of having a forkhead domain. These transcription factors play a role in regulating the cell cycle, cell differentiation, apoptosis and cell resistance to oxidative stress [29]. In mammals, there are isoforms from Fox01, such as FoxO3, Fox04, and Fox06. Fox01 is found in the adult pancreatic $\beta$ cells but is not found in other pancreatic cells such as acinus cells, $\alpha$ cells, $\delta$ cells, and PP cells [30].

The role of FoxO1 in pancreatic $\beta$-cell proliferation and apoptosis is related to the function of the Pancreatic and Duodenal Homeobox 1 (PDX1 gene). The PDX1 gene is the primary gene that plays a role in pancreatic cell embryogenesis. In the embryogenesis phase, the PDX1 expression is abundant in pancreatic $\beta$-cells, and this expression decreases after reaching adulthood. The physiological expression of PDX1 is found in the nucleus while Fox01 is found in the cytoplasm [31]. The phosphorylation of Fox01 is regulated by insulin via the phosphoinositide 3 kinase-Akt pathway. Phosphorylation of Fox01 in the cytoplasm activates the work of the cyclin D1 and Cyclin Dependent Kinase-4 (CDK4) proteins activating the cell cycle from the G0 to G1 phase in preparation for DNA synthesis [32]. However, several factors are reported to cause the migration of FoxO1 to the nucleus. High blood glucose levels, hyperlipidemia, and the aging process are examples of factors that cause the migration of FoxO1 to the nucleus [33]. Inside the nucleus, Fox01 will compete with FoxA1 to occupy the PDX1 promoter DNA. FoxA1 includes a transcription protein from the Forkhead protein family, which is a positive regulator of PDX1. The bond between Fox01 and PDX1 promoters causes apoptosis [31].

Fox01 plays a role in the process of pancreatic endocrine cell differentiation. Talchai et al. proved that experimental animals that do not express Fox01 in the cytoplasm of pancreatic $\beta$-cells will experience hyperglycemia and pancreatic $\beta$ cell mass reduction after stress induction. Based on the in vitro study, it was shown that the cell death process did not cause pancreatic $\beta$-cell reduction; this occurred as the result of the differentiation of $\beta$-cells into embryonic progenitor cells expressing Neurogenin 3, Oct 4, Nanog, and L-Myc. In addition, it was proven that the loss of FoxO1 in the cytoplasm caused an increase in the number of $\alpha$ cells, and Pancreatic Peptide (PP) cells, and a decrease in pancreatic $\beta$-cells characterized by a decrease in the activity of the genes activity that control insulin synthesis, GLUT transporters, and glucokinase enzyme production [34].

Computational approaches have been developed to predict the ability of an active compound contained in a plant to produce biological effects. One such method is based on molecular docking analysis [35]. The principle of molecular docking is to predict the ability of a ligand to bind with a target protein to form a stable complex. The ability of a ligand to bind to the active site of a receptor is then analyzed to assess the strength of activation or inhibition [36]. Thus, this study identified the active compounds of soursop leaf water extract through physicochemical analyses and GC-MS and predicted its mechanism of action as an anti-obesity compound based on the in silico analysis.

\section{MATERIALS AND METHODS}

\section{Experimental design}

This study utilized laboratory-based research to identify the active compounds of soursop leaf and computational calculations to predict its ability to activate GLP-1R, inhibiting DPP4 and FOX01 proteins.

\section{Date and place}

The study was carried out in December 2017 and January 2018. It was conducted in the Biochemistry laboratory of Universitas Islam, Malang, the Bioinformatics Laboratory of Universitas Brawijaya, Malang, and the Mineral and Advanced Materials Laboratory of Universitas Negeri Malang. 


\section{Soursop leaf extraction}

Soursop leaves were obtained from Balai Materia Medika, Batu City, East Java. Selected soursop leaves (middle leaf, undamaged, glossy surface) were washed and dried in the wind out of direct sunlight until they reached $10 \%$ moisture content. The dried leaves were then milled to form a powder. This powder was placed in a decoction pan, and water was added in a 1:10 powder-to-water ratio. The bottom of the pan was filled with water and boiled to 100 $\circ C$. The pan contain ing the soursop leaf pow der and $w$ ater $w$ as placed on the decoction of water for $15 \mathrm{~min}$ and stirred continuously. After cooling down, the resulting extract was filtered using Whatman No. 1 paper [37]. The filtrate was then reduced using an evaporator at a temperature of $60{ }^{\circ} \mathrm{C}$ until the volume reached about $1 / 3$ of the original amount [38].

Identification of soursop active compound based on a physicochemical method
The soursop's active compounds were identified in the laboratory using the physicochemical method. Samples ( $5 \mathrm{~g}$ each) were ground with a mortar. Then, each sample was inserted into a separating funnel which had been filled with a mixture of chloroform and water $(60 \mathrm{ml}: 60 \mathrm{ml})$ then gently stirred for $20 \mathrm{~min}$. They were incubated until 2 layers of chloroform-water were formed followed by the separation of the water phase and the chloroform phase. The water phase was used to test the secondary metabolites, i.e., flavonoids, phenolics, and saponins, while the chloroform phase was used to test the alkaloids, terpenoids, and steroids.

\section{Identification of active ingredients of soursop based on the GC-} MS analysis method

The water extract $(10 \mathrm{ml})$ was mixed with a hexane solution $(1: 1$ $\mathrm{v} / \mathrm{v})$, and then mixed and separated using a separating funnel. Hexane extract was used for GC-MS analysis using Shimadzu GC-MS with optimization tools as seen in table 1 .

Table 1: GC-MS optimization

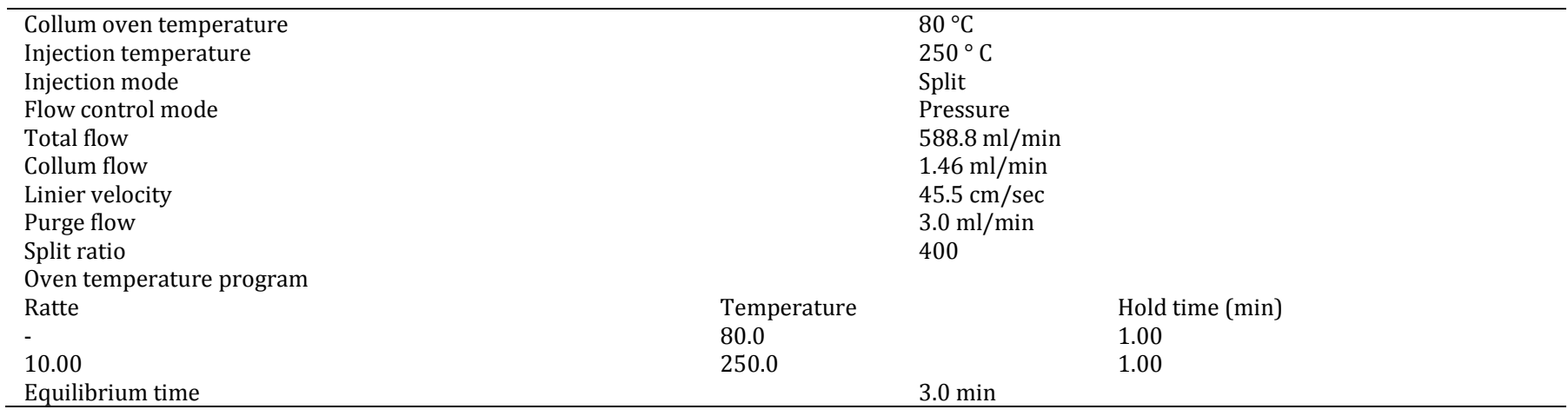

The results of the GC-MS analysis were converted based on the Wiley8. Lib database. The molecular weights of the active compounds were compared with the same molecular weights of compounds in the database [39]. The highest Similarity Index (SI) molecular wieght between active compound and some compound in data base indicated the high validity of identification.

\section{Analysis based on in silico studies}

The active compounds were downloaded from the PubChem server (CID was noted). The potential for activation of GLP-1R, DPP4, and FOX01 protein was analyzed using the Way2drug web server. Prediction of potential compounds was indicated by probability activity (PA) score. GLP-1R, DPP4 and FOX01 protein were obtained from the protein database server. Drug control was taken from the PubChem. The active compound interaction of soursop leaf water extract with GLP-1R was predicted by using the STITCH program
[40]. The PyRx program (autodock vina) was used for the docking process [41]. Docking was carried out precisely with 1-cyclohexene1-carbonitrile, 6-acettyloxy; 1,2-benzenedicarboxylic acid, dietyl ester; 2(E)-tert-butyl-4-methyleneadamantan-2(A)-ol; and 5isopropenyl-3, 8-dimethyl-1,2,3,3A, 4,5,6,7-octahydroazulene as a ligand and GLP-1R, DPP4 and Fox01 as the target proteins to be compared to controls. The smallest or most negative binding energy results showed the best complex conformation. The docking results were visualized using Ligandscout and PyMol [42].

\section{RESULTS}

\section{Physicochemical Identification of Soursop Leaf}

The physiochemical analyses of the soursop leaf determined that it contains many active compounds, including flavonoids, phenols, alkaloids, and terpenoids, but did not contain saponins or steroids (table 2).

Table 2: List of active compounds found in soursop leaf water extract

\begin{tabular}{llll}
\hline No & Compound & Test method & Color changes \\
\hline 1 & Flavonoid & HCL 0,2N & Brownish yellow \\
2 & Fenol & FeCl3 & Purplish blue \\
3 & Saponin & vigorously mixed for $10 \mathrm{~s}$ & Permanent foam \\
4 & Alkaloid & Meyer reagent & White sediment \\
5 & Terpenoid & anhydra acetate+H2SO4 2N & Positive \\
6 & Steroid & anhydra acetate+H2SO4 2N & Pegative \\
\hline
\end{tabular}

Note: It was found that soursop leaf water extract contained many active compounds-flavonoids, phenols, alkaloids, and terpenoids-but did not contain saponins and steroids.

\section{Identification of soursop leaf water extract active compounds based on the GC-MS method}

The active compounds of soursop leaf water extract were successfully identified via GC-MS analysis.

Based on fig. 2 and 3 and table 3 as well as the results on the active compounds based on the MS confirmation to the Wiley8. Lib database. 


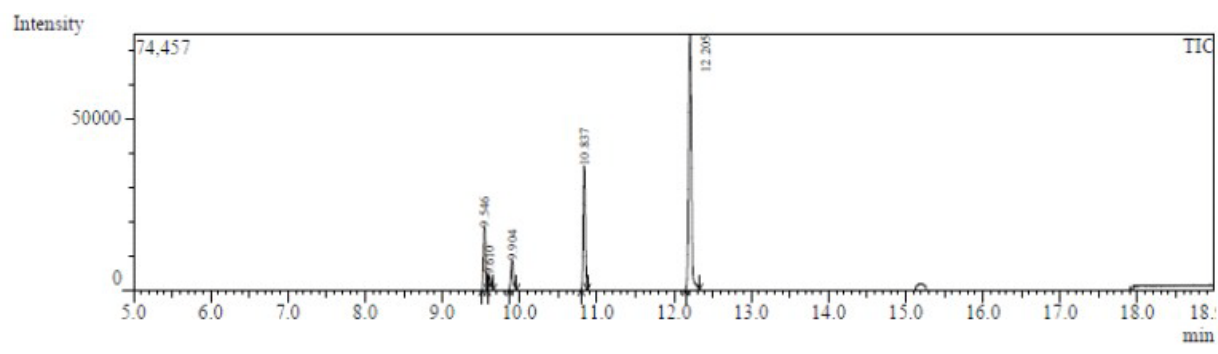

Fig. 2: Active compound of soursop results identified via GC-MS analysis, note: soursop leaf water extract was determined to contain 5 active compounds by the appearance of 5 peaks with RT 9.546; 9.60; 9.904; 10.837 and 12.205

Line\#:2 R.Time:9.608(Scan\#:554) MassPeaks:2
RawMode:Averaged 9.600-9.617(553-555) BasePeak:122.15(2846)

BG Mode:Calc. from Peak Group 1 - Event 1

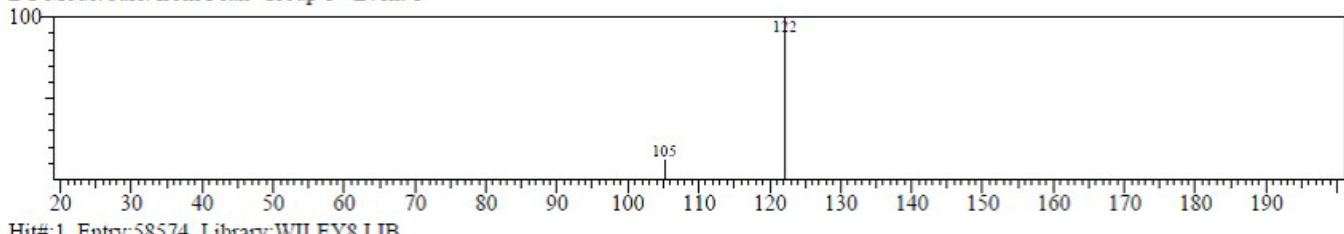

Hit\#:1 Entry:58574 Library:WILEY8.LIB

SI:97 Formula:C9H11NO2 CAS:130251-99-9 MolWeight:165 RetIndex:0

CompName:1-CYCLOHEXENE-1-CARBONITRILE, 6-(ACETYLOXY)-, (.+-)- \$\$ ACETOXY-6 CYANO-1 CYCLOHEXENE

Line\#: 3 R. Time: 9.900 (Scan\#:589) MassPeaks:5

RawMode:Averaged 9.892-9.908(588-590) BasePeak:163.10(2874)

BG Mode:Calc. from Peak Group 1 - Event

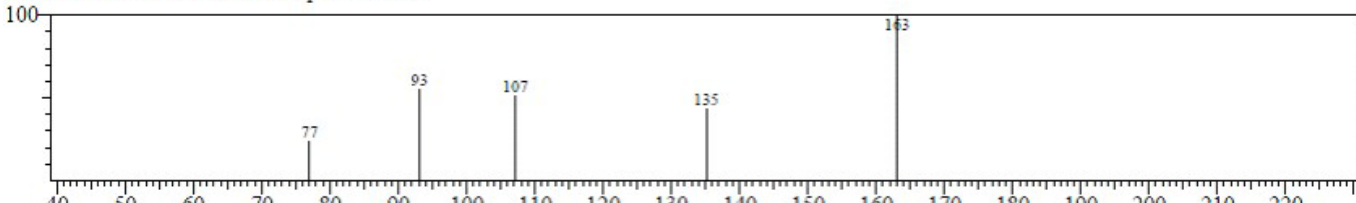

Hit\#:1 Entry:132968 Library:WILEY8.LIB

SI:82 Formula:C15H24O CAS:0-00-0 MolWeight:220 RetIndex:0

CompName:2(E)-TERT-BUTYL-4-METHYLENEADAMANTAN-2(A)-OL

Line\#-4 R. Time: 10.833 (Scan=701) MassPeaks:18

RawMode:Averaged 10.825-10.842(700-702) BasePeak:93.10(3840)

BG Mode:Calc. from Peak Group 1 - Event 1

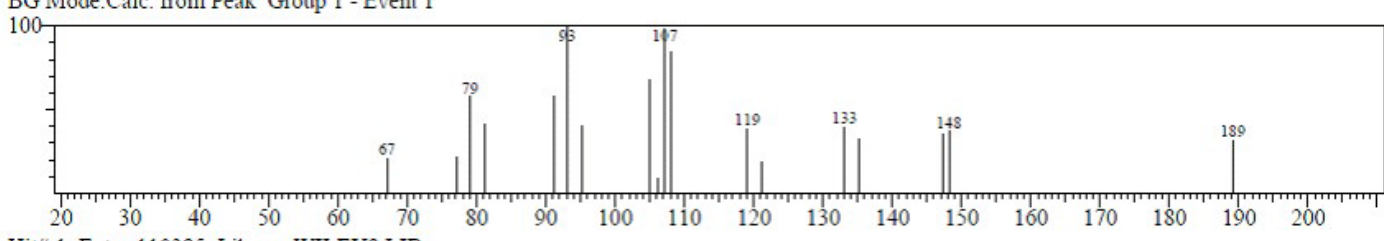

Hit\#:1 Entry:110385 Library:WILEY8. LIB

SI:85 Formula:C15H24 CAS:0-00-0 MolWeight:204 RetIndex:0

CompName:5-ISOPROPENYL-3,8-DIMETHYL-1,2,3,3A,4,5,6,7-OCTAHYDROAZULENE SS DELTA-GUAJEN (ALPHA-BULNESEN)

Line\#:5 R.Time:12.208(Scan\#:866) MassPeaks:14

RawMode:Averaged 12.200-12.217(865-867) BasePeak:149.10(33539)

BG Mode:Calc. from Peak Group 1 - Event 1

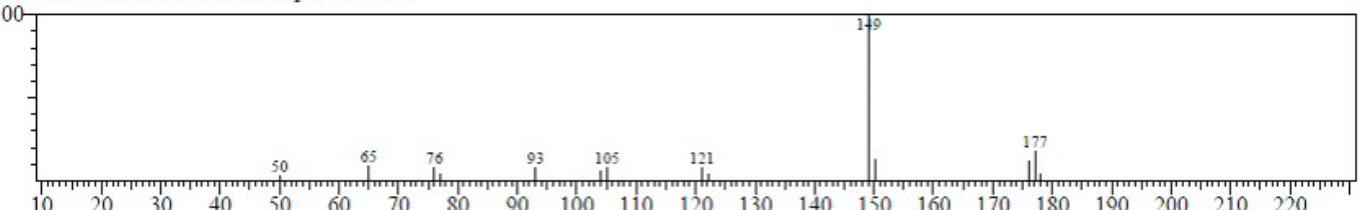

Hit\#:1 Entry:134833 Library:WILEY8.LIB

SI:93 Formula:C12H14O4 CAS:84-66-2 MolWeight:222 RetIndex:0

CompName:1,2-BENZENEDICARBOXYLIC ACID, DIETHYL ESTER \$S PHTHALIC ACID \$\$ -BENZENEDICARBOXYLIC ACID DIETHY]

Fig. 3: The mass spectra of the active compounds of soursop obtained via GC-MS analysis, active compound in the first peak (RT 9.546) are not identified in data base wileylab8

Table 3: The active compounds obtained based on the GC-MS analysis

\begin{tabular}{lllllllll}
\hline Peak & SI & R. T & Area \% & MW & Name & CAS/CID & Class & Structure \\
\hline $\mathbf{2}$ & 97 & 9.608 & 2.84 & 165 & $\begin{array}{l}\text { 1-cyclohexene-1-carbonitrile,6- } \\
\text { acettyloxy }\end{array}$ & $\begin{array}{l}\text { CAS 130251- } \\
\text { 99-9 }\end{array}$ & phenolic \\
\end{tabular}




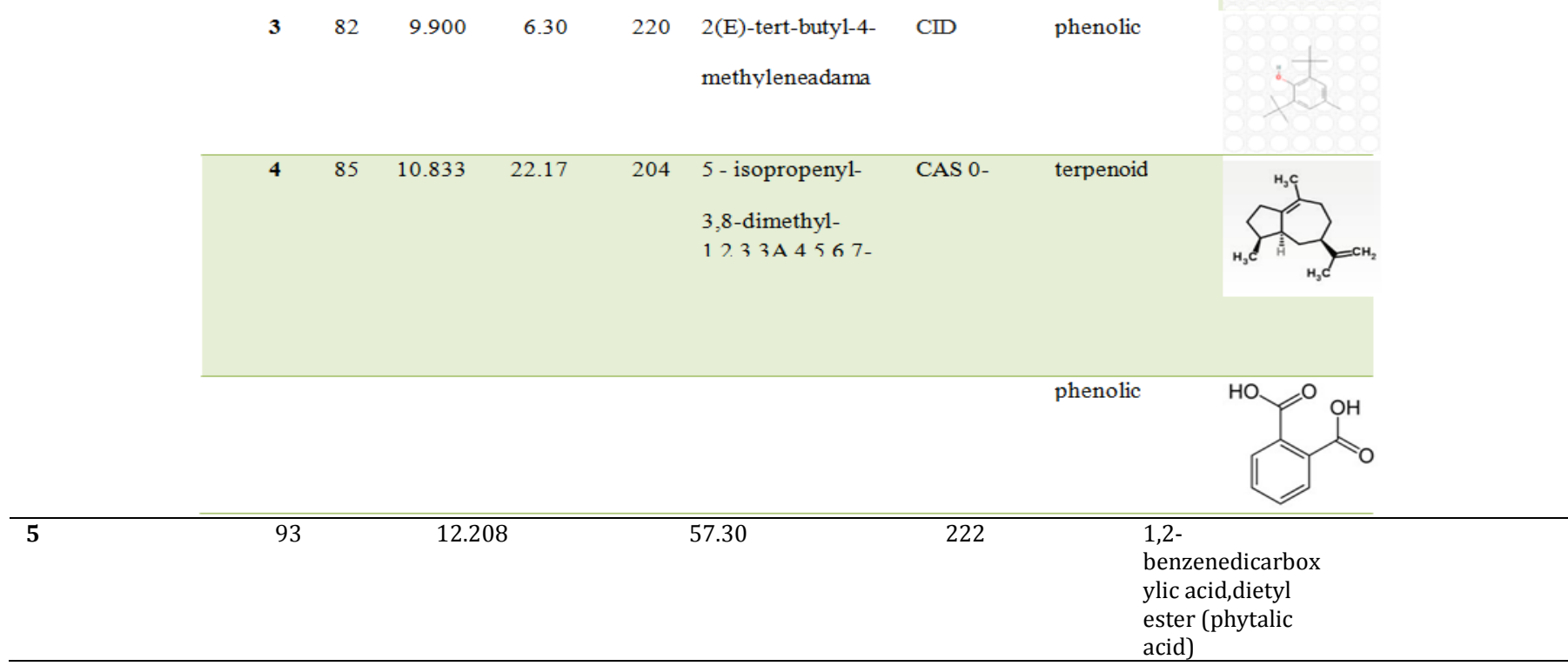

Note: Soursop leaf was containing water extract contain flavonoids, phenols, terpenoids, and alkaloids. SI: similary index, R. T: real time; MW: molecular weight

Potential analysis of soursop leaf water extract's active compounds

Analysis using the Way2drug web server shows that the 5isopropenyl-3, 8-dimethyl-1,2,3,3A, 4,5,6,7-octahydroazulene and phthalic acid are predicted by bioinformatics to have the ability to be antioxidant and insulin promoter $(\mathrm{Pa}>0,4)$.
The interaction prediction of GLP-1R with active compounds of soursop leaf water extract

The interaction of GLP-1R with soursop's active compounds was predicted using the STITCH program. The results of the analysis showed that Phthalic acid did not bind to the GLP-1 receptor but interacted with hydrogen peroxide (fig. 4).

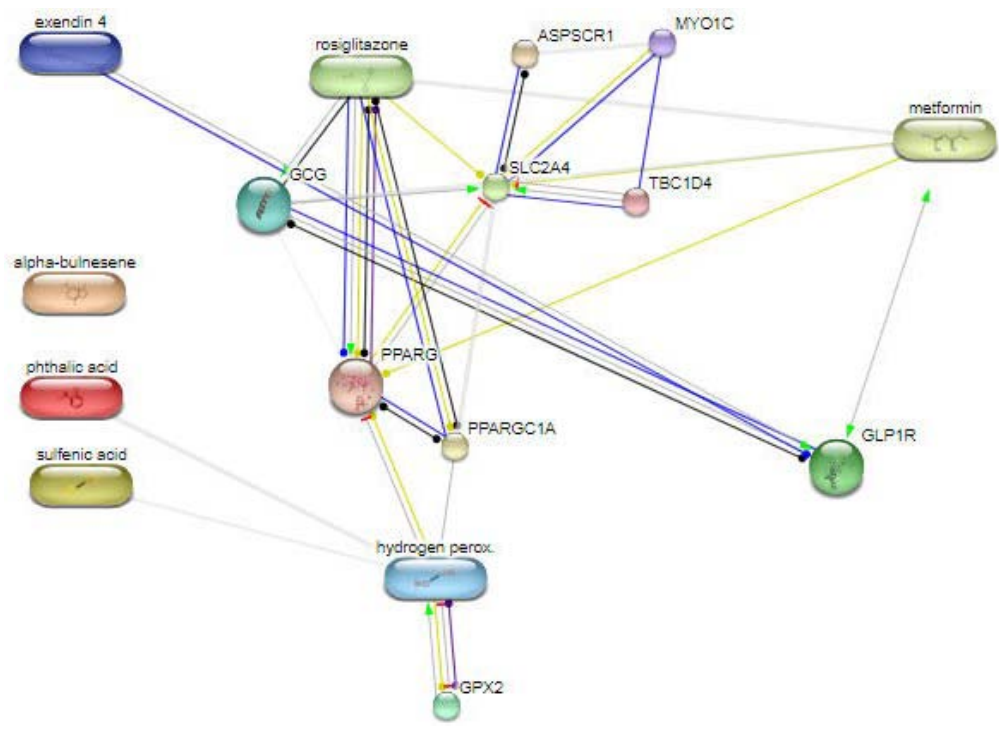

Fig. 4: The active compounds of soursop with the GLP-1 receptor. Active compounds of soursop leaf water extract did not have a interactions with GLP-1R

The binding potential of soursop leaf water extracts active compounds with the DPP4 and Fox01 target proteins

Molecular docking was used to determine the binding potential of the active compounds found in the soursop leaf water extract with the DPP4 and Fox01 target proteins. It was also used to determine the most active compounds based on the affinity value of each compound to a protein. The affinities of the active compounds contained in soursop leaf water extract for DPP4 protein were tested using Linagliptin, a drug that can inhibit the DPP4 enzyme [43], as a 
control; it was determined that phthalic acid and 5-isopropenyl-3, 8dimethyl-1,2,3,3A, 4,5,6,7-octahydroazulene have lower affinities for DPP4 than controls. The affinities of the active compounds contained in soursop leaf water extract to Fox01 protein were determined using AS1842856 (PubChem ID: 72193864), a compound that can inhibit FoxO-1 [44], as a control. The active compound identified as phthalic acid has a lower affinity towards the Fox01 protein than the control (table 4).

Table 4: Molecular docking active ingredient of soursop (A. muricata $L$.) leaf water extract against DPP4 and Fox01 target protein

\begin{tabular}{lll}
\hline Active compound & $\begin{array}{l}\boldsymbol{\Delta ~ G ~ ( k k a l / m o l ) ~ a g a i n s t ~ D P P 4 ~} \\
\text { protein }\end{array}$ & $\begin{array}{l}\boldsymbol{\Delta ~ G ~ ( k k a l / m o l ) ~ a g a i n s t ~ F o x 0 1 ~} \\
\text { protein }\end{array}$ \\
\hline 1-cyclohexene-1-carbonitrile, 6-acettyloxy & -6 & -3.6 \\
1,2-benzenedicarboxylic acid, dietyl ester & -6 & -4.5 \\
2(E)-tert-butyl-4-methyleneadamantan-2(A)-ol & -6.2 & -2.4 \\
5-isopropenyl-3, 8-dimethyl-1,2,3,3A, 4,5,6,7-octahydroazulene & -6.9 & -3.61 \\
Kontrol & -10 & -6.1 \\
\hline
\end{tabular}

Note: Docking process using the PyRx program (autodock vina). The control of DPP4 inhibitors using Linagliptin. Control of Fox01 inhibitors using AS1842856 (PubChem ID: 72193864 ).

\section{DISCUSSION}

Identification of the active compounds in soursop leaf water extract

GC-MS results showed that there are five active compounds in soursop leaf water extract. Phthalic acid (57,30\%) and 5isopropenyl-3,8-dimethyl-1,2,3,3A, 4,5,6,7-octa hydro azulene $(22,17 \%)$ are the most active ingredient contained in soursop leaf water extract. There is one active compound unidentified because it cannot be found in data base wileylab8. Researchers suspect such active compund have never been found previous or not researched so this is not recorded in base data used as confirmation. Researchers recommend using other tools as confirmation of such active materials.

\section{Potential analysis of soursop leaf water extract's active compounds}

The potential test results showed that 5-isopropenyl-3, 8-dimethyl1,2,3,3A, 4,5,6,7-octahydroazulene and phthalic acid had potential as antioxidant and insulin promoters with $\mathrm{P}(\mathrm{a})>0.4$. This indicated that computational predictions still required laboratory verification both in vitro and in vivo to support these allegations. Previous research stated that the water extract of soursop leaves given for 3 $\mathrm{w}$ at $100 \mathrm{mg} / \mathrm{kgBW}$ was able to increase endogenous antioxidant and increase the serum insulin levels of STZ-induced hyperglycemia in mice [45]. However, the active compound(s) that works as an insulin promoter has not been identified.

The interaction prediction of GLP-1R protein with the soursop leaf water extract active compounds

The active compound of soursop leaf water extract has not been shown to directly interact with GLP-1R proteins. This is assumed to be due to the lack of similarity in the chemical structure of the active compounds and GLP-1R, so they are unable to bind to the active site of the GLP-1R. Phthalic acid has been shown to interact with hydrogen peroxide. This is assumed phthalic acid have antioxidant potency.

The binding Potential of Soursop Leaf Water Extract's Active Compounds with the DPP4 target protein

Linagliptin was used as the control in this study. Linagliptin is a drug that has the effect of inhibiting DPP4 competitively and reversibly. Linagliptin's inhibition potency to DPP4 was better than related drugs, including sitagliptin, vildagliptin, and saxagliptin [43]. From the results of molecular docking, it was found that the free bonding energy of linagliptin to the DPP4 protein was $-10 \mathrm{kcal} / \mathrm{mol}$. This indicated that linagliptin has a high affinity with DPP4 and can form strong and stable bonds that further inhibit the DPP4.

Molecular docking results from the active compounds of soursop leaf water extract showed that 5-isopropenyl-3,8-dimethyl-1,2,3,3A, 4,5,6,7-octa hydro azulene ( $\Delta \mathrm{G}$ of- $6.9 \mathrm{kcal} / \mathrm{mol}$ ) and phthalic acid had the best affinity to the DPP4 protein $(\Delta \mathrm{G}$ of $-6.9 \mathrm{kcal} / \mathrm{mol})$ compared to other compounds. However, free bonding energy $(\Delta \mathrm{G})$ 5-isopropenyl-3,8-dimethyl-1,2,3,3A, 4,5,6,7-octa hydro azulene and phthalic acid were greater than control. It can be predicted that 5 isopropenyl-3,8-dimethyl-1,2,3,3A, 4,5,6,7-octa hydro azulene, and phthalic acid have a weak potential to inhibit the DPP4. Although it was weak, the synergy found was expected as an insulin promoter through the prevention of GLP-1 degradation by DPP4.

Potential of soursop leaf water extract's active compounds towards the Fox01 target protein

AS1842856 was used as a control to determine the affinity of the active compounds contained in the water extract of soursop leaf with the FoxO1 target protein. AS1842856 is an active small molecule identified as 5-amino-7-(cyclohexyl-amino)-1-ethyl-6fluoro-4-oxo-1,4-dihydroquinoline-3-carboxylic acid (PubChem ID: 72193864). Based on the in silico analysis, AS1842856 is a compound that can inhibit FOXO-1 [44]. Other studies have suggested that the in vitro administration of AS1842856 to liver cell lines has caused a decrease in glucose production. Based on a previous in vivo study, it was also shown that the application of AS1842856 was able to reduce blood glucose levels in DM mice [46]. The results of previous studies proved that other active compounds of soursop leaf, e. g., annonain, routine, muricatocin A, isolaureline, xylophone, and kaempferol 3-0-rutinoside, showed affinities with the Fox01 protein with the same or better potential as AS1842856 based on the in silico analysis [44].

The molecular docking results showed that phthalic acid's active compound weakly inhibited Fox01. The results ofG with Fox01 indicated it was greater than- $7 \mathrm{kcal} / \mathrm{mol}$. In general, the Fox01 protein is abundant in the cytoplasm [31]. Fox01 activation in the cytoplasm is regulated by insulin. The phosphorylation of Fox01 activates the action of the cyclin D1 and cdk4 proteins, which regulate the cell cycle of pancreatic $\beta$-cell proliferation [32]. However, high glucose levels, hyperlipidemia, and the aging process will cause the translocation of FoxO1 to the nucleus [33]. The activation of Fox01 in the nucleus will cause PDX-1 gene inhibition. This gene plays a role in regulating pancreatic $\beta$-cell proliferation. The bond between Fox01 and PDX1 promoters causes apoptosis [31]. Fox01 plays a role in the process of endocrine cell differentiation. Fox01 activity in the cytoplasm causes the differentiation of $\beta$-cells into embryonic progenitor cells $[34,47]$.

\section{CONCLUSION}

The active compounds found in soursop leaf water extract were phthalic acid (BM 222) (57.30\%), and 5-isopropenyl-3,8-dimethyl1,2, 3,3A, 4,5,6,7-octahydroazulene (BM 204) (22.17\%). These two active compounds have a weak affinity with DPP4. Only phthalic acid has a weak affinity to FoxO-1. Phthalic acid as predicted was able to inhibit DPP4 and Fox01 activity in the nucleus. However, in vivo studies based on research using animal models are needed to verify the predictions that have been generated from the computational process.

\section{ACKNOWLEDGMENT}

This article was presented at The $3^{\text {rd }}$ International Conference and Exhibition on Indonesian Medical Education and Research Institute (ICE on IMERI 2018), Faculty of Medicine, Universitas Indonesia, 
Jakarta, Indonesia. This research was funded by the Dean of the Medical Faculty UNISMA. This research was conducted in collaboration with the Bioinformatics from University of Brawijaya, research assistant from Medical Faculty UNISMA, and University of Malang. We thank the $3^{\text {rd }}$ ICE on IMERI Committee who had supported the peer review and manuscript preparation before submitting to the journal.

\section{AUTHORS CONTRIBUTIONS}

All the author have contributed equally

\section{CONFLICT OF INTERESTS}

The authors declared no conflict of interest

\section{REFERENCES}

1. Budijanto D. Profil Kesehatan Indonesia. Jakarta: Kementerian Kesehatan Republik Indonesia; 2017.

2. Ekor M. The growing use of herbal medicines: issues relating to adverse reactions and challenges in monitoring safety. Front Pharmacol 2014;4:1-10.

3. Elfahmi, Woerdenbag HJ, Kayser O. Jamu: Indonesian traditional herbal medicine towards rational phytopharmacological use. J Herb Med 2014;69:1-23.

4. Morton, Julia F. The Soursop, Or Guanabana (Annona Muricata). Florida Atlantic University; 1966. p. 355-66.

5. Nwokocha CR, Owu DU, Gordon A, Thaxter K, McCalla G, Ozulua $\mathrm{RI}$, et al. Possible mechanisms of action of the hypotensive effect of Annona muricata (soursop) in normotensive spraguedawley rats. Pharm Biol 2012;50:1436-41.

6. Florence NT, Benoit MZ, Jonas K, Alexandra T, Desire DD, Pierre $\mathrm{K}$, et al. Antidiabetic and antioxidant effects of annona muricata (Annonaceae), aqueous extract on streptozotocin-induced diabetic rats. J Ethnopharmacol 2014;151:784-90.

7. Ishola IO, Awodele O, Olusayero AM, Ochieng CO. Mechanisms of analgesic and anti-inflammatory properties of annona muricata linn. (Annonaceae) fruit extract in rodents. J Med Food 2014; 17:1375-82.

8. Cercato LM, White PA, Nampo FK, Santos MR, Camargo EA. A systematic review of medicinal plants used for weight loss in Brazil: is there potential for obesity treatment? J Ethnopharmacol 2015;176:286-96.

9. George V Cijo. Antioxidant, DNA protective efficacy and HPLC analysis. J Food Sci Technol 2015;52:2328-35.

10. Agbai EO, Njoku CJ, Nwanegwo CO, Nwafor A. Effect of aqueous extract of Annona muricata seed on atherogenicity in streptozotocin-induced diabetic rats. Afr J Pharm Pharmacol 2015;9:745-55.

11. Patel S, Patel JK. A review on a miracle fruits of Annona muricata. J Pharmacogn Phtochem 2016;5:137-48.

12. Pai BHM, Rajesh G, Shenoy R, Rao A. Anti-microbial efficacy of soursop leaf extract (Annona muricata) on oral pathogens: an in vitro study. J Clin Diagn Res 2016;10:ZC01-ZC04.

13. Bikomo EO, Ebuehi OAT, Magbagbeola A. Antidepressant activity of ethanol leaf extract of annona muricata L, in spraque-dawley rats. Am J Biochem 2017;7:1-5.

14. Yajid AI, Ab Rahman HS, Wong MPK, Zain WZW. Potential benefits of annona muricata. Malays J Med Sci 2018;25:5-15.

15. Moghadamtousi SZ, Fadaeinasab M, Nikzad S, Mohan G, Ali HM, Kadir HA. Annona muricata (Annonaceae): a review of its traditional uses, isolated acetogenins and biological activities. Int J Mol Sci 2015;16:15625-58.

16. Nik Mat Daud MM, Yaakob H, Mohamad Rosdi MN. Acetogenins of annona muricata leaves: characterization and potential anticancer study. Integr Cancer Sci Therap 2016;3:543-51.

17. James WP. WHO recognition of the global obesity epidemic. Int J Obes 2008;32(Suppl 7):S120-S126.

18. Segula D. Complications of obesity in adults: a short review of literature. Malawi Med J 2014;26:20-4.

19. Garber AJ. Long-acting glucagon-like peptide 1 receptor agonists. Diabetes Care 2011;34(Suppl 2):S279-S282.

20. Madsbad S. The role of glucagon-like peptide-1 impairment in obesity and potential therapeutic implications. Diabetes Obes Metab 2014;16:9-21.
21. Harbener JF, Kiefer TJ. Glucagon and glucagon like peptides. In: Joslin's Diabetes Mellitus. 14th edition. Editor. CR Kahn, GL King, AC Moses, GC Weir, AM Jacobson, RJ Smith. Philadelphia: Lippincott Willams and Wilkins; 2005. p. 179-90.

22. Sandoval DA, Dalessio DA. Physiology of proglucagon peptides: role of glucagon and GLP-1 in health and disease. Physiol Rev 2015;95:513-48.

23. Donnelly D. The structure and function of glucagon-like peptide-1 and its ligands. Br J Pharmacol 2012;166:27-41.

24. Druker DJ, Sherman SI, Gorelick FS, Bergenstal RM, Sherwin RS, Buse JB. Incretin-based therapies for the treatment of type 2 diabetes: evaluation of the risks and benefits. Diabetes Care 2010;33:428-33.

25. Van Bloemendaal L, Ten Kulve JS, Ia Fleur SE, Ijzerman RG, Diamant M. Effects of glucagon-like peptide 1 on appetite and body weight: focus on the CNS. J Endocrinol 2014;221:T1-16.

26. Reimann F, Gribble FM. Mechanisms underlying glucosedependent insulinotropic polypeptide and glucagon-like peptide-1 secretion. J Diabetes Investigation 2016;7(Suppl 1):13-9.

27. Buteau J, Spatz ML, Accili D. Transcription factor Fox01 mediates glucagon-like peptide-1 effects on pancreatic beta-cell mass. Diabetes 2006;55:1190-6.

28. Fusco J, Xiao X, Prasadan K, Sheng Q, Chen C, Ming YC. GLP$1 /$ Exendin-4 induces $\beta$-cell proliferation via the epidermal growth factor receptor. Sci Rep 2017;7:1-6.

29. Greer EL, Brunet A. FOXO transcription factors at the interface between longevity and tumor suppression. Oncogene 2005;24:7410-25.

30. Kitamura T, Ido Kitamura Y. Role of FoxO proteins in pancreatic beta cells. Endocr J 2007;54:507-15.

31. Kitamura YI, Kitamura T, Kruse JP, Raum JC, Stein R, Gu W, et al Fox01 protects against pancreatic beta cell failure through NeuroD and MafA induction. Cell Metab 2005;2:153-63.

32. Okamoto H, Hribal ML, Lin HV, Bennett WR, Ward A, Accili D. Role of the forkhead protein FoxO1 in beta cell compensation to insulin resistance. J Clin Invest 2006;116:775-82.

33. Gross DN, Van den Heuvel AP, Birnbaum MJ. The role of FoxO in the regulation of metabolism. Oncogene 2008;27:2320-36.

34. Talchai C, Xuan S, Lin HV, Sussel L, Accili D. Pancreatic $\beta$-cell dedifferentiation as mechanism of diabetic $\beta$-cell failure. Cell 2012;150:1223-34.

35. Wadood A, Ahmed N, Shah L, Ahmad A, Hassan H, Shams S. In silico drug design: An approach which revolutionarised the drug discovery process. OA Drug Design Delivery 2013;1:3.

36. De Ruyck J, Brysbaert G, Blossey R, Lensink MF. Molecular docking as a popular tool in drug design, an in silico travel. Adv Appl Bioinform Chem 2016;9:1-11.

37. Félix Silva J, Souza T, Menezes YA, Cabral B, Camara B, Camara $\mathrm{RB}$, et al. Aqueous leaf extract of Jatropha gossypiifolia L. (Euphorbiaceae) inhibits enzymatic and biological actions of bothrops jararaca snake venom. PLoS One 2014;9:e104952.

38. Oyedeji O, Taiwo FO, Ajayi OS, Ayinde F, Oziegbe M, Oseghare CO. Biocidal and phytochemical analysis of leaf extracts of annona muricata (Linn.). Int J Sci: Basic Appl Res 2015;24:7687.

39. Ezhilan BP, Neelamegam R. GC-MS analysis of phytocomponents in the ethanol extract of polygonum chinense L. Pharmacognosy Res 2012;4:11-4.

40. Szklarczyk D, Santos A, Von Mering C, Jensen LJ, Bork P, Kuhn M. STITCH 5: augmenting protein-chemical interaction networks with tissue and affinity data. Nucleic Acids Res 2016;44:D380-D384.

41. Dallakyan S, Olson AJ. Small-molecule library screening by docking with PyRx. Methods Mol Biol 2015;1263:243-50.

42. Seeliger D, de Groot BL. Ligand docking and binding site analysis with PyMOL and Autodock/Vina. J Computer Aided Mol Des 2010;24:417-22.

43. Gallwitz B. Emerging DPP-4 inhibitors: focus on linagliptin for type 2 diabetes diabetes. Diabetes Metab Syndr Obes 2013;6:19.

44. Damayanti DS, Utomo DH, Kusuma C. Revealing the potency of Annona muricata leaves extract as FOX01 inhibitor for diabetes mellitus treatment through computational study. In Silico Pharmacol 2016;5:3. 
45. Adewole SO, Ojewole JA. Protective effects of annona muricata Linn. (Annonaceae) leaf aqueous extract on serum lipid profiles and oxidative stress in hepatocytes of streptozotocin-treated diabetic rats. Afr J Traditional 2008;6:30-41.

46. Nagashima T, Shigematsu N. Maruki R, Urano Y, Tanaka H, Shimaya A, et al. Discovery of novel forkhead box 01 inhibitors for treating type 2 diabetes: improvement of fasting glycemia in diabetic db/db mice. Mol Pharmacol 2010;78:961-70.

47. Zhang T, Kim DH, Xiao X, Lee S, Gong Z, Muzumdar R. Fox01 plays an important role in regulating-cell compensation for insulin resistance in male mice. Endocrinology 2016; 157:1055-70. 